\title{
Pengembangan media pembelajaran ipa berbantuan komputer pada materi gerak lurus untuk siswa SMP/MTs kelas VIII
}

\author{
Ardiansyah Fitrul Firdaus, Winarto*, Safwatun Nida \\ Universitas Negeri Malang, Jl. Semarang No. 5 Malang, Jawa Timur, Indonesia \\ *Penulis korespondensi, Surel: winarto.fmipa@um.ac.id
}

Paper received: 01-02-2021; revised: 15-02-2021; accepted: 28-02-2021

\begin{abstract}
The purpose of this study is to produce Science instructional media of computer-assisted on the subject of linear motion for eighth graders which fit to use. This research is a development being done using 4-D Thiagarajan development model which done to development stage. The research data used is quantitative and qualitative data. Data was collected using a validation and test legibility questionnaires. The data analysis techniques used is qualitative descriptive analysis and averages calculation techniques. Results of media and of material validations obtained that the percentage of media feasibility is 93.33 percent and the percentage of material feasibility is 85,52 percent with the percentage of validity concept is 95,83 percent, while the legible test results showed that the learning media can be accepted by the students. Based on the results of validation and legible test can be concluded that the instructional media developed feasible to use in learning.
\end{abstract}

Keywords: Science Instructional Media; Computer-Assisted; Linier Motion

\begin{abstract}
Abstrak
Tujuan penelitian ini adalah untuk menghasilkan media pembelajaran IPA berbantuan komputer pada materi gerak lurus untuk siswa SMP/MTs kelas VIII yang layak digunakan. Penelitian ini merupakan penelitian pengembangan yang dilakukan dengan menggunakan model pengembangan 4-D Thiagarajan yang dilakukan hanya sampai pada tahap Develop. Data penelitian yang digunakan berupa data kuantitatif dan kualitatif. Data dikumpulkan dengan menggunakan instrumen berupa angket validasi dan angket uji keterbacaan. Teknik analisis data yang digunakan adalah teknik analisis deskriptif kualitatif dan teknik penghitungan rata-rata. Hasil validasi media dan validasi materi diperoleh persentase kelayakan media sebesar 93,33 persen dan persentase kelayakan materi sebesar 85,52 persen dengan persense kebenaran konsep sebesar 95,83 persen, sedangkan hasil uji keterbacaan menunjukkan bahwa media pembelajaran dapat diterima oleh siswa. Berdasarkan hasil validasi dan uji keterbacaan dapat disimpulkan bahwa media pembelajaran yang dikembangkan layak untuk digunakan di dalam pembelajaran.
\end{abstract}

Kata kunci: Media Pembelajaran IPA; Berbantuan Komputer; Gerak Lurus

\section{Pendahuluan}

Pembelajaran IPA diawali dengan cara mencari tahu tentang alam secara sistematis, bukan hanya penguasaan kumpulan pengetahuan tetapi juga merupakan suatu proses penemuan (Minawati, dkk., 2014). Menurut Trianto (2014), pembelajaran IPA seharusnya menekankan pada keterampilan siswa untuk memahami alam dan gejalanya melalui proses mencari tahu secara langsung. Proses mencari tahu dapat dilakukan dengan cara mengamati fenomena dan gejala secara langsung yang terjadi di kehidupan sehari-hari yang berhubungan dengan materi IPA.

Salah satu materi IPA yang dipelajari di SMP adalah materi gerak lurus. Materi tersebut mengacu pada Kompetensi Dasar (KD) 3.1 kelas VIII kurikulum 2013 yang menyatakan bahwa siswa harus memahami gerak lurus dan pengaruh gaya terhadap gerak berdasarkan 
Hukum Newton. Pada jenjang SMP, materi tentang gerak yang diajarkan yakni mencakup kinematika dan dinamika. Sebelum mempelajari mengenai dinamika, maka siswa harus memahami konsep pada materi kinematika. Dasar dari materi kinematika adalah waktu, jarak, kecepatan, dan percepatan (Ruiz, 2009). Ketika belajar tentang materi kinematika, siswa akan diajarkan mengenai posisi, kecepatan, dan percepatan (Sutopo, 2012).

Menurut Nurani, dkk. (2013) sebagian besar siswa mengalami kesulitan belajar pada materi gerak lurus, hal ini dikarenakan banyak terdapat persamaan-persamaan yang dirasa sulit untuk dipahami. Sulitnya memahami materi gerak lurus dikarenakan sebagian besar materi tersebut bersifat abstrak (Abu bakar \& Rahmatsyah, 2012). Sifat dari materi gerak lurus yang abstrak tersebut menyebabkan siswa sering mengalami kesulitan membedakan antara kecepatan dan percepatan (Hake, 1998). Menurut Nuroso \& Siswanto (2010) sifat dari materi kinematika yang abstrak tersebut menyebabkan siswa harus memiliki penalaran formal.

Pada kenyataannya menurut teori Jean Peaget menyatakan bahwa siswa SMP 11-15 tahun berada pada tahapan transisi antara berfikir konkrit menuju berifikir abstrak (Trianto, 2011), hal ini menyebabkan siswa kesulitan memahami materi pelajaran. Kesulitan siswa dalam memahami materi pelajaran, terutama yang abstrak dikarenakan dalam proses pembelajarannya hanya menggunakan metode ceramah, sehingga siswa kurang terlibat aktif selama proses pembelajaran. Metode pembelajaran yang demikian mengakibatkan pembelajaran tidak bermakna. Penelitian lain yang dilakukan oleh Taufiq (2012) menyatakan bahwa proses pembelajaran yang kurang bermakna menjadikan siswa sulit memahami materi yang diajarkan, sehingga berpengaruh pada kompetensi yang dimiliki siswa tersebut, terutama kompetensi pada ranah kognitif.

Penilaian ranah kognitif dilakukan dengan mengukur kemampuan siswa dalam menguasai konsep IPA, namun kenyataan di lapangan menunjukkan bahwa penguasaan konsep IPA siswa SMP masih rendah (Anggraeni, 2013). Hal tersebut dibuktikan dengan hasil wawancara yang dilakukan terhadap guru mata pelajaran IPA di Kabupaten Lamongan yang mengatakan bahwa, sebagian besar siswa harus mengikuti remidi (ujian ulang) untuk mencapai nilai KKM. Berdasarkan hasil wawancara yang dilakukan terhadap siswa SMP di Kota Batu diketahui bahwa terdapat masalah lain dalam pembelajaran IPA khususnya materi gerak lurus yaitu selama proses pembelajaran siswa hanya menggunakan buku paket dan lembar kerja sebagai sumber belajar, hal ini mengakibatkan siswa merasa bosan dan malas untuk belajar karena sumber belajar siswa kurang memadai. Sumber belajar dikatakan kurang memadai karena menurut Minawati (2014) sumber belajar tidak memberikan pengalaman belajar bagi siswa.

Kesulitan memperoleh sumber belajar yang mendukung proses pembelajaran dapat dibantu dengan penggunaan media (Sedyawati, 2013). Menurut Kurniawan (2013), penggunaan media pembelajaran dalam proses belajar dapat meningkatkan pemahaman konsep dan membantu siswa untuk menerima informasi dengan seluruh panca indra. Menurut Ali (2009), fungsi media dalam proses belajar mengajar yaitu untuk meningkatkan rangsangan siswa dalam kegiatan belajar.

Salah satu alternatif media pembelajaran saat ini adalah dengan memanfaatkan perkembangan teknologi terutama memanfaatkan komputer. Pentingnya pemanfaatan komputer dalam dunia pendidikan dikarenakan ilmu pengetahuan tidak dapat terlepas dari 
perkembangan teknologi. Salah satu manfaat dari penggunaan media pembelajaran berbantuan komputer adalah materi yang abstrak dapat divisualisasikan dalam bentuk gambar, teks, video, animasi, dan suara (Pradana, 2014). Penggunaan media pembelajaran berbantuan komputer juga dapat menghemat waktu persiapan mengajar, meningkatkan motivasi belajar siswa, dan mengurangi kesalahpahaman siswa terhadap penjelasan yang diberikan guru (Ali, 2005). Penggunaan media pembelajaran berbantuan komputer mempunyai pengaruh yang signifikan terhadap daya tarik siswa untuk mempelajari kompetensi yang ada (Ali, 2009).

Berdasarkan uraian yang telah dipaparkan di atas, maka perlu dilakukan penelitian yang berjudul "Pengembangan Media Pembelajaran IPA Berbantuan Komputer Pada Materi Gerak Lurus Untuk Siswa SMP/MTs Kelas VIII”.

\section{Metode}

Media pembelajaran berbantuan komputer yang dikembangkan ini mengacu pada model penelitian dan pengembangan yang dikembangkan oleh Thiagarajan, Semmel dan Semmel yang terdiri dari empat tahap yang dikenal dengan model 4-D (four D Model) (Thiagarajan dkk, 1974). Model tersebut terdiri dari tahap pendefinisian (define), tahap perancangan (design), tahap pengembangan (develop) dan tahap penyebaran (disseminate). Pada penelitian ini, tahapan pengembangan yang dilakukan oleh peneliti adalah dengan menggunakan modifikasi model pengembangan 4-D hanya sampai pada tahap develop, untuk tahap disseminate tidak dilakukan. Tahapan define dilakukan untuk menetapkan dan mendefinisikan segala kebutuhan yang diperlukan dalam pengembangan multimedia. Tahap design bertujuan untuk mendesain prototipe multimedia yang akan dikembangkan. Tahapan pengembangan bertujuan untuk menghasilkan multimedia yang layak dan valid. Tahapan ini mencakup pengembangan prototipe, desain uji coba produk, dan revisi produk.

Desain uji coba penelitian ini meliputi kegiatan validasi dan uji keterbacaan. Validasi dilakukan oleh ahli media dan ahli materi. Validasi oleh ahli media dilakukan untuk mengetahui kelayakan produk dari aspek tampilan dan cara penyajian, sedangkan validasi oleh ahli materi dilakukan untuk mengetahui kelayakan produk dari aspek konten materi. Uji coba keterbacaan dilakukan pada siswa SMP kelas VIII yang telah mendapatkan materi gerak lurus. Instrumen yang digunakan untuk mengumpulkan data dalam penelitian pengembangan ini berupa angket. Angket yang digunakan terdiri dari angket penilaian ahli materi, angket penilaian ahli media, dan angket uji keterbacaan siswa. Instrumen pengumpulan data dilengkapi dengan aspek yang akan dinilai beserta skala bertingkat yang digunakan sebagai panduan dalam penilaian setiap aspek yang akan dinilai. Pada instrumen pengumpulan data, skala penilaian yang digunakan adalah skala Likert.

Teknik analisis data pada penelitian pengembangan ini ada dua macam yaitu teknik analisis deskriptif untuk data kualitatif yang berupa komentar dan saran, dan teknik perhitungan rata-rata untuk data kuantitatif dari perolehan skor penilaian setiap aspek yang dinilai. Data kuantitatif digunakan untuk mengumpulkan hasil penilaian ahli dan siswa mengenai produk media pembelajaran berbantuan komputer yang dikembangkan sehingga dapat dianalisis kriteria kelayakan produk dengan melihat rata-rata penilaian produk untuk semua aspek yang dinilai. 
Tabel 1 Tingkat Kriteria Kelayakan Media Pembelajaran

\begin{tabular}{ll}
\hline Presentase (\%) & Kriteria \\
\hline $30-39$ & Tidak baik/ tidak layak (revisi total) \\
$40-55$ & Kurang baik/ kurang layak (revisi) \\
$56-65$ & Cukup baik/ cukup layak \\
$66-79$ & Baik/ layak \\
$80-100$ & Sangat baik/ sangat layak \\
\hline
\end{tabular}

\section{Hasil dan Pembahasan}

\section{Deskripsi Produk Pengembangan}

Produk yang dihasilkan merupakan aplikasi media pembelajaran berbantuan komputer yang dapat memfasilitasi siswa kelas VIII untuk memahami materi gerak lurus. Aplikasi ini dapat digunakan oleh guru di dalam pembelajaran maupun oleh siswa ketika belajar mandiri. Aplikasi ini terdiri dari tiga bagian utama yaitu opening, beranda home, dan akhir. Bagian opening terdiri atas halaman opening dan bar loading. Bagian halaman home terdiri atas enam konten multimedia. Bagian akhir terdiri atas sound dan penutup. Gambar 1 merupakan beberapa tampilan dari media yang telah dikembangkan.
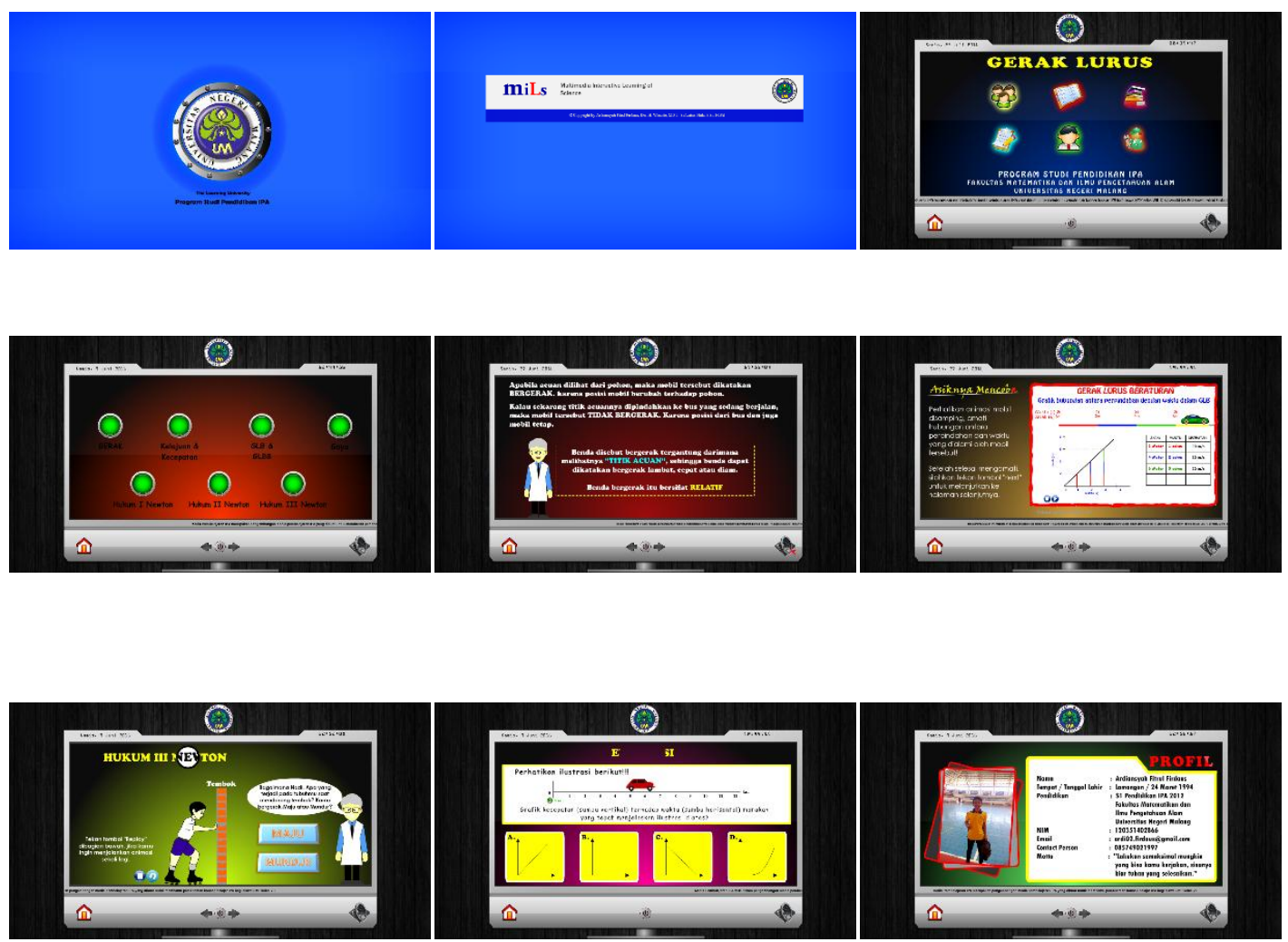


\section{Hasil Validasi}

Validasi media dilakukan oleh 3 orang validator yang bertindak sebagai ahli media dan ahli materi. Validator I dan II merupakan seorang dosen Program Studi IPA FMIPA UM, dan validator III merupakan seorang guru IPA SMPN 4 Lamongan. Validator I dan validator III bertindak sebagai ahli media, sedangkan validator II dan validator III bertindak sebagai ahli materi. Data kuantitatif hasil validasi ahli media disajikan pada Tabel 2.

\section{Tabel 2 Hasil Analisis Data Kuantitatif Validasi Ahli Media}

\begin{tabular}{llll}
\hline Aspek & Rerata & Persentase (\%) & Kriteria \\
\hline Desain & 4,50 & 90,00 & Sangat Layak \\
Penyajian materi & 4,50 & 90,00 & Sangat Layak \\
Fasilitas & 5,00 & 100,00 & Sangat Layak \\
\hline Rerata Kelayakan Media & 4,64 & 93,33 & Sangat Layak \\
\hline
\end{tabular}

Validasi oleh ahli media dilakukan terhadap 3 aspek penilaian yaitu desain, penyajian materi, dan fasilitas. Berdasarkan Tabel 1 dapat diketahui bahwa dari aspek desain, penyajian materi, dan fasilitas, media pembelajaran ini memperoleh persentase penilaian sebesar 90,00\%, 90,00\%, dan 100,00\%. Kelayakan media secara umum memperoleh persentase sebesar 93,33\%, sehingga media pembelajaran ini dikatakan sangat layak untuk digunakan.

Selain data kuantitatif, dari kegiatan validasi media juga diperoleh data kualitatif berupa komentar dan saran validator yang dijadikan sebagai bahan untuk melakukan revisi produk. Komentar dan saran dari masing-masing validator ditunjukkan pada Tabel 3.

Tabel 3. Data Kualitatif Hasil Validasi Media

\begin{tabular}{lll}
\hline Validator & Komentar & Saran \\
\hline I & - & $\begin{array}{l}\text { Animasi pada subbab gerak dan GLB sebaiknya sekali jalan saja. } \\
\text { Pada GLBB, animasi sebaiknya dibuat lebih halus pergerakannya. }\end{array}$ \\
\hline III & - & $\begin{array}{l}\text { Animasi Mobil pada GLBB sebaiknya dibuat sekali jalan saja, } \\
\text { jangan berulang-ulang. }\end{array}$ \\
\hline
\end{tabular}

Validasi materi dilakukan terhadap kelayakan materi dan kebenaran konsep. Hasil validasi kelayakan materi dan kebenaran konsep disajikan pada Tabel 4 dan Tabel 5.

Tabel 4. Hasil Analisis Data Kuantitatif Validasi Ahli Materi

\begin{tabular}{llll}
\hline Aspek & Rerata & Persentase (\%) & Kriteria \\
\hline Kemudahan memahami petunjuk penggunaan & 4,00 & 80,00 & $\begin{array}{l}\text { Sangat } \\
\text { Layak } \\
\text { Kesesuaian tujuan pembelajaran dengan }\end{array}$ \\
$\begin{array}{l}\text { Sangat } \\
\text { kompetensi dasar }\end{array}$ & 4,00 & 80,00 & $\begin{array}{l}\text { Layak } \\
\text { Sangat } \\
\text { Kelayakan isi }\end{array}$ \\
$\begin{array}{llll}\text { Layak } \\
\text { Penyajian isi }\end{array}$ & 4,44 & 88,75 & $\begin{array}{l}\text { Sayat } \\
\text { Layak }\end{array}$ \\
\hline Rerata Kelayakan Materi & 4,67 & 93,33 & $\begin{array}{l}\text { Sangat } \\
\text { Layak }\end{array}$ \\
\hline
\end{tabular}


Tabel 5. Hasil Validasi Kebenaran Konsep

\begin{tabular}{lll}
\hline No & Aspek Penilaian & Persentase Kelayakan \\
\hline 1 & Gerak & $100 \%$ \\
& Benda dikatakan Bergerak & $100 \%$ \\
& Benda dikatakan Tidak bergerak & $100 \%$ \\
\hline & Gerak benda bersifat relatif & \\
\hline 2 & Kecepatan dan Kelajuan \\
& Konsep Kecepatan & $100 \%$ \\
& Konsep Kelajuan & $100 \%$ \\
\hline 3 & Gerak Lurus Beraturan dan Gerak Lurus Berubah Beraturan \\
& Gerak Lurus Beraturan & $100 \%$ \\
& Gerak Lurus Berubah Beraturan & $100 \%$ \\
\hline 4 & Gaya & $100 \%$ \\
& Gaya Gesek & $100 \%$ \\
\hline & Gaya Berat (Gravitasi) & $50 \%$ \\
& Hukum-Hukum Newton & $100 \%$ \\
& Hukum I Newton & $100 \%$ \\
\hline & Hukum II Newton & $95,83 \%$ \\
\hline
\end{tabular}

Hasil validasi kelayakan materi diperoleh persentase kelayakan sebesar 85,52\%. Selain itu, hasil validasi kebenaran konsep diperoleh persentase kebenaran konsep sebesar 95,83\% atau dengan kata lain masih terdapat konsep yang perlu diperbaiki. Kesalahan konsep terletak pada sub materi hukum I Newton khususnya pada penggunaan kalimat yang menjelaskan bunyi dari hukum I Newton. Perbaikan konsep yang belum tepat dilakukan pada tahap revisi produk, sehingga diakhir revisi produk dihasillkan media pembelajaran yang menyajikan ketepatan konsep secara menyeluruh. Berdasarkan hasil validasi tersebut dapat disimpulkan bahwa media pembelajaran yang dikembangkan sangat layak untuk digunakan di dalam pembelajaran dari segi materi.

Selain data kuantitatif, dari kegiatan validasi materi juga diperoleh data kualitatif berupa komentar dan saran validator yang dijadikan sebagai bahan untuk melakukan revisi produk. Komentar dan saran dari masing-masing validator ditunjukkan pada Tabel 6 dan Tabel 7.

Tabel 6. Data Kualitatif Hasil Validasi Kelayakan Materi

\begin{tabular}{lll}
\hline Validator & Komentar & Saran \\
\hline II & $\begin{array}{l}\text { Grafik hubungan v dan t pada GLBB } \\
\text { diperbaiki } \\
\text { Redaksi kalimat dalam soal evaluasi } \\
\text { diperbaiki }\end{array}$ & \\
\hline III & & $\begin{array}{l}\text { Penggunaan bahasa pengantar } \\
\text { supaya lebih ditingkatkan }\end{array}$ \\
\hline
\end{tabular}

Tabel 7. Data Kualitatif Hasil Validasi Kebenaran Konsep

\begin{tabular}{lll}
\hline Validator & Komentar & Saran \\
\hline II & Penjelasan tentang gerak bersifat & Animasi pada hukum II Newton \\
& relatif diperbaiki lagi. & sebaiknya massanya yang di variasi, \\
& Gambar tentang mobil untuk & sedangkan gaya yang diberikan sama.
\end{tabular}




\begin{tabular}{|c|c|c|}
\hline & $\begin{array}{l}\text { menjelaskan perpindahan perlu } \\
\text { diperbaiki } \\
\text { Redaksi soal diperbaiki agar tidak salah } \\
\text { konsep. } \\
\text { Gerakan mobil pada GLB dan GLBB } \\
\text { diperbaiki lagi } \\
\text { Gerak mobil dipercepat belum tampak } \\
\text { Istilah "perlambatan" itu tidak ada } \\
\text { Gambar pada submateri Gaya } \\
\text { diperbaiki } \\
\text { Definisi Hukum I Newton masih kurang } \\
\text { tepat. } \\
\text { Animasi pada Hukum II Newton diubah } \\
\text { contohnya. }\end{array}$ & $\begin{array}{l}\text { Vektor gaya aksi dan reaksi pada } \\
\text { Hukum III Newton harus sama } \\
\text { panjangnya. }\end{array}$ \\
\hline III & \multicolumn{2}{|c|}{$\begin{array}{l}\text { Pada kesimpulan gerak bersifat relatif sebaiknya menggunakan katanyang jelas } \\
\text { dalam kalimat } \\
\text { Sebaiknya setelah konsep kelajuan diberi materi pengembangan seperti yang ada } \\
\text { pada "kecepatan", yaitu "kelajuan termasuk besaran skalar'. }\end{array}$} \\
\hline
\end{tabular}

\section{Hasil Uji Keterbacaan}

Berdasarkan hasil pengisian angket yang disebarkan kepada 15 orang siswa kelas VIII SMP As Salam Batu, diperoleh data kualitatif yang disajikan pada Tabel 8.

Tabel 8 Rekapitulasi Data Jawaban Siswa dari Uji Keterbacaan

\begin{tabular}{|c|c|c|}
\hline No & Pertanyaan & Jawaban Siswa \\
\hline 1 & $\begin{array}{l}\text { Apakah menurut Anda pemilihan background } \\
\text { menarik? Berikan alasannya! }\end{array}$ & 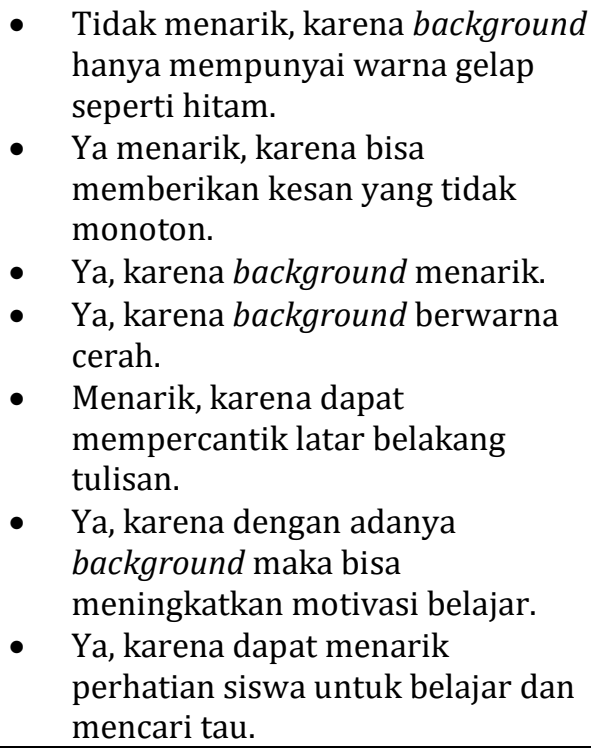 \\
\hline 2 & $\begin{array}{l}\text { Apakah tampilan media menarik dan memotivasi } \\
\text { Anda untuk belajar? Berikan alasannya! }\end{array}$ & $\begin{array}{l}\text { - Ya, karena dari tampilan media } \\
\text { siswa dapat belajar dengan cara } \\
\text { baru. } \\
\text { - Ya menarik, karena dari tampilan } \\
\text { media yang menarik memudahkan } \\
\text { saya dalam belajar. } \\
\text { - Ya tampilan media memotivasi } \\
\text { saya karena didukung dengan } \\
\text { gambar yang menarik pula. }\end{array}$ \\
\hline
\end{tabular}




\begin{tabular}{|c|c|c|}
\hline & & $\begin{array}{l}\text { - } \quad \text { Sangat menarik, karena berkat } \\
\text { media ini saya lebih mudah paham } \\
\text { saat belajar. }\end{array}$ \\
\hline 3 & $\begin{array}{l}\text { Apakah gambar/ilustrasi dan animasi menarik? } \\
\text { Berikan alasannya! }\end{array}$ & $\begin{array}{l}\text { - } \quad \text { Iya, karena disaat kita belajar } \\
\text { dengan melihat ilustrasi dapat } \\
\text { meningkatkan pemahaman. } \\
\text { - } \quad \text { Ya, karena gambarnya bagus dan } \\
\text { menarik. } \\
\text { - } \quad \text { Iya, karena menurut saya gambar } \\
\text { dan animasinya mudah diingat. } \\
\text { - Sangat menarik, karena gambar } \\
\text { dan ilustrasi sering terjadi } \\
\text { dikehidupan. } \\
\text { Ya, karena banyak warna sehingga } \\
\text { ilustrasi lebih bagus dan lebih } \\
\text { menarik. }\end{array}$ \\
\hline 4 & $\begin{array}{l}\text { Apakah gambar/ilustrasi dan animasi yang } \\
\text { digunakan membantu pemahaman Anda? Berikan } \\
\text { alasannya! }\end{array}$ & $\begin{array}{l}\text { - } \quad \text { Ya, karena mudah dipahami. } \\
\text { - } \quad \text { Ya, karena saya lebih mengerti } \\
\text { - } \quad \text { mudah masuk ke otak. } \\
\text { - } \quad \text { Iya, karena membantu mengingat } \\
\text { materi dan dapat mengurangi } \\
\text { kejenuhan disaat belajar. } \\
\text { - Sangat membantu, karena gambar } \\
\text { yang disajikan sesuai dengan } \\
\text { materi yang dipelajari. }\end{array}$ \\
\hline 5 & $\begin{array}{l}\text { Bagaimanakah menurut Anda kesesuaian ukuran, } \\
\text { jenis dan warna huruf yang digunakan? }\end{array}$ & $\begin{array}{l}\text { - } \quad \text { Tulisan sudah sesuai karena } \\
\text { mudah dilihat. } \\
\text { Sangat baik, karena kita bisa } \\
\text { membedakan catatan-catatan } \\
\text { pentingnya. } \\
\text { - Sangat sesuai, karena ukuran, } \\
\text { jenis, dan warna dapat dilihat } \\
\text { dengan jelas. } \\
\text { - Sangat sesuai, karena ukuran } \\
\text { huruf yang tidak terlalu kecil dan } \\
\text { warna huruf yang pas sehingga } \\
\text { mudah dilihat. } \\
\text { Sudah bagus, karena tulisannya } \\
\text { dapat dibaca dengan jelas. }\end{array}$ \\
\hline 6 & $\begin{array}{l}\text { Apakah bahasa yang digunakan untuk } \\
\text { menjelaskan materi mudah dipahami? Berikan } \\
\text { alasannya! }\end{array}$ & $\begin{array}{l}\text { - Ya, karena tidak terlalu } \\
\text { menggunakan bahasa yang } \\
\text { bertele-tele (rumit). } \\
\text { - Ya, karena bahasa yang digunakan } \\
\text { seperti bahasa yang digunakan } \\
\text { sehari-hari. } \\
\text { - Ya, karena menggunakan bahasa } \\
\text { - Indonesia. } \\
\text { Ya, karena mudah dingat. }\end{array}$ \\
\hline 7 & $\begin{array}{l}\text { Apakah penyusunan tombol dapat } \\
\text { mempermudah penggunaan media ini? Berikan } \\
\text { alasannya! }\end{array}$ & $\begin{array}{l}\text { - Ya, karena saya lenih mudah } \\
\text { untuk membedakan antar subbab } \\
\text { satu dengan yang lainnya. } \\
\text { - Iya, karena mempermudah } \\
\text { pengoperasian media. }\end{array}$ \\
\hline
\end{tabular}




\begin{tabular}{|c|c|c|}
\hline & & 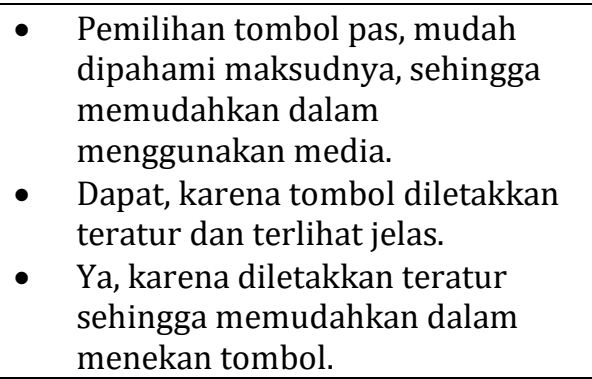 \\
\hline 8 & $\begin{array}{l}\text { Apakah tampilan media pembelajaran ini } \\
\text { terstruktur sehingga mempermudah anda } \\
\text { mengenali sub-sub pokok bahasan di dalamnya? } \\
\text { Berikan alasannya! }\end{array}$ & $\begin{array}{l}\text { - } \quad \text { Ya, saya mengerti. } \\
\text { - } \quad \text { Ya, materinya sudah sesuai } \\
\text { struktur. } \\
\text { Sangat terstruktur, karena dari } \\
\text { media pembelajaran yang } \\
\text { terstruktur saya lebih mudah } \\
\text { menangkap sub-sub pokok } \\
\text { bahasan. } \\
\text { - Ya, materi terstruktur karena } \\
\text { disajikan secara runtut. } \\
\text { Ya, karena meteri yang disajikan } \\
\text { dimulai dari materi termudah } \\
\text { hingga paling rumit. } \\
\text { - Ya, karena didalamnya sangat } \\
\text { lengkap. }\end{array}$ \\
\hline 9 & $\begin{array}{l}\text { Apakah secara keseluruhan materi yang } \\
\text { disampaikan dalam media ini mudah untuk } \\
\text { dipahami? Jika tidak, materi apa yang masih sulit } \\
\text { dipahami? Berikan alasannya! }\end{array}$ & $\begin{array}{l}\text { - } \quad \text { Masih sedikit sulit dipahami } \\
\text { karena tidak ada rumus pokok. } \\
\text { - Ya, seluruh materi yang } \\
\text { disampaikan mudah dipahami } \\
\text { karena didukung oleh media yang } \\
\text { menarik. } \\
\text { - Ya mudah dipahami, materi } \\
\text { disajikan dengan jelas dan } \\
\text { dilengkapi berbagai gambar dan } \\
\text { video. } \\
\text { Ya mudah dipahami, penampilan } \\
\text { ilustrasi dan gambar memudahkan } \\
\text { pemahaman. }\end{array}$ \\
\hline 10 & $\begin{array}{l}\text { Apakah media pembelajaran ini dapat membantu } \\
\text { Anda memahami hubungan antara materi yang } \\
\text { Anda pelajari dengan penerapannya di dalam } \\
\text { kehidupan? Berikan alasannya! }\end{array}$ & $\begin{array}{l}\text { - Ya, karena ada ilustrasi untuk bisa } \\
\text { dicontoh saat menerapkan materi } \\
\text { dikehidupan sehari-hari. } \\
\text { - Ya, karena pada media } \\
\text { pembelajaran banyak } \\
\text { menggunakan contoh pada } \\
\text { kehidupan sehari-hari. } \\
\text { - Ya, karena ilustrasi dan video yang } \\
\text { ditampilkan berasal dari } \\
\text { kehidupan sehari-hari. }\end{array}$ \\
\hline
\end{tabular}

Berdasarkan hasil analisis terhadap data kuantitatif uji keterbacaan diketahui bahwa produk media pembelajaran yang dikembangkan dapat diterima dengan baik. Sebagian besar siswa memberikan respon jawaban positif terhadap media pembelajaran yang dikembangkan dan merasa lebih mudah memahami konsep dengan menggunakan media pembelajaran ini. Data kualitatif berupa komentar dan saran yang diberikan oleh siswa menunjukkan bahwa 
sebagian besar siswa memberikan komentar yang baik untuk media pembelajaran. Oleh karena itu, produk media pembelajaran ini layak untuk digunakan di dalam pembelajaran.

\section{Simpulan}

\section{KESIMPULAN}

Hasil akhir dari penelitian pengembangan ini adalah dihasilkan produk berupa media pembelajaran berbantuan komputer pada materi gerak lurus. Multimedia pembelajaran yang dikembangkan berdasarkan KD 3.1 kelas VIII semester ganjil kurikulum 2013 yaitu memahami gerak lurus dan pengaruh gaya terhadap gerak berdasarkan hukum Newton, serta penerapannya pada gerak makhluk hidup dan gerak benda dalam kehidupan sehari-hari. Multimedia yang dikembangkan secara garis besar terdiri dari tiga bagian utama yaitu opening, halaman home, dan akhir.

Berdasarkan hasil analisis validasi yang telah dilakukan diperoleh hasil persentase kelayakan media sebesar 93,33\%, persentase kelayakan materi sebesar 85,52 \% dan persentase kebenaran konsep sebesar 95,83\%. Berdasarkan uji keterbacaan yang telah dilakukan diperoleh respon yang baik dari siswa SMP As Salam Batu. Berdasarkan hasil validasi dan uji keterbacaan dapat disimpulkan bahwa produk media pembelajaran yang dikembangkan sudah memenuhi kriteria kelayakan yakni sangat layak untuk digunakan di dalam pembelajaran.

\section{SARAN}

Saran untuk pengembangan produk lebih lanjut adalah dengan melakukan uji coba produk pada skala yang lebih luas dalam kegiatan pembelajaran pada KD 3.1 kelas VIII semester ganjil sehingga dapat diketahui keefektifan media pembelajaran berbantuan komputer yang dikembangkan. Media pembelajaran berbantuan komputer yang telah dikembangkan diharapkan dapat dijadikan rujukan oleh peneliti lain dalam pengembangan sumber belajar pada kompetensi dasar yang sama maupun berbeda. Pengembangan lebih lanjut diharapkan akan menghasilkan produk yang lebih baik dengan adanya perbaikan atau penambahan konten di dalam produknya.

\section{Daftar Rujukan}

Ali, M. (2009). Pengembangan media pembelajaran interaktif mata kuliah medan elektromagnetik. Jurnal edukasi elektro, 5(1).

Ali, M. (2005). Pengembangan bahan pembelajaran berbantuan komputer untuk memfasilitasi belajar mandiri dalam mata diklat penerapan konsep dasar listrik dan elektronika di SMK. Laporan Penelitian Research Grant PHK A2 Jurusan Pendidikan Teknik Elektro FT UNY.

Anggareni, N. W., Ristiati, N. P., \& Widiyanti, N. L. P. M. (2013). Implementasi strategi pembelajaran inkuiri terhadap kemampuan berpikir kritis dan pemahaman konsep IPA siswa SMP. Jurnal Pendidikan dan Pembelajaran IPA Indonesia, 3(1).

Bakar, A. (2012). Menerapkan Model Konstruktivis Untuk Meningkatkan Hasil Belajar Fisika Umum I Mahasiswa Semester I Jurusan Fisika Fmipa Unimed Ta 2012/2013. Jurnal Pendidikan Fisika, 1(2), 4954.

Hake, R. R. (1998). Interactive-engagement versus traditional methods: A six-thousand-student survey of mechanics test data for introductory physics courses. American journal of Physics, 66(1), 64-74.

Kurniawan, A. D. (2013). Metode inkuiri terbimbing dalam pembuatan media pembelajaran biologi untuk meningkatkan pemahaman konsep dan kreativitas siswa SMP. Jurnal Pendidikan IPA Indonesia, 2(1). 
Minawati, Z., Haryani, S., \& Pamelasari, S. D. (2014). Pengembangan Lembar Kerja Siswa IPA Terpadu Berbasis Inkuiri Terbimbing Pada Tema Sistem Kahidupan Dalam Tumbuhan Untuk Smp Kelas VIII. Unnes Science Education Journal, 3(3).

Nurani, G. S. (2013). Penerapan peta konsep dalam pembelajaran untuk meningkatkan hasil belajar fisika pada pokok bahasan gerak lurus siswa kelas VII A SMP NEGERI 1 Gumelar (Doctoral dissertation, Universitas Negeri Semarang).

Nuroso, H., \& Siswanto, J. (2010). Model Pengembangan Modul Ipa1terpadu Berdasarkan Perkembangan Kognitif Siswa1. Jurnal Penelitian Pembelajaran Fisika, 1(1).

Pradana, D. A. (2014). Pengembangan multimedia pembelajaran interaktif mata pelajaran IPA kelas VIII SMP NU Pakis Malang (Doctoral dissertation, Universitas Negeri Malang).

Ruiz, M. J. (2009). Kinematic measurements from YouTube videos. The Physics Teacher, 47(4), 200-203.

Sedyawati, SMR., Haryani, S., Heriyanto, A. (2013). Pengembangan Multimedia Pembelajaran Interaktif Berbasis Education Game Sebagai Media Pembelajaran Kimia. Jurnal Kimia Universitas Negeri Semarang. 3 (1): 2.

Sutopo, P. K. B. D. G. (2012). Cara Baru Dalam Pengajaran Kinematika. Prosiding Smeinar Nasional Penelitian, Pendidikan, dan Penerapan MIPA, Fakultas MIPA, Universitas Negeri Yogyakarta, 2.

Taufiq, M. (2012). Remediasi miskonsepsi mahasiswa calon guru fisika pada konsep gaya melalui penerapan model siklus belajar (learning cycle) 5E. Jurnal Pendidikan IPA Indonesia, 1(2).

Thiagarajan, S., Semmel, D. S., \& Semmel, M. I. (1974). Instructional development for training teachers of exceptional children.

Trianto. (2011). Model Pembelajaran Terpadu : Konsep, Strategi, dan Implementasinya dalam Kurikulum Tingkat Satuan Pendidikan (KTSP). Jakarta: Bumi Aksara.

Trianto, T. (2014). Model Pembelajaran Terpadu; Konsep, Strategi dan Implementationnya dalam KTSP. Jakarta: Bumi Aksara. 